\title{
The Influence of Board of Director Gender Diversity on Gendered Corporate Social Responsibility
}

\author{
Wenlu McIntosh \\ College of Business Administration \\ Boise State University \\ Boise, Idaho, USA \\ John C. McIntosh ** \\ Department of Management \\ College of Business Administration \\ Boise State University \\ Boise, Idaho, USA \\ Email: Johnmcintosh@Boisestate.edu \\ USA
}

\section{ABSTRACT}

This paper examines the impact of board of director gender diversity on organizational outcomes associated with gendered corporate social responsibility (GCSR). The study employs a sample of 458 companies reported in the 2018 RobecoSam sustainability report to examine the relationship between the board of director gender diversity (GD) to GCSR performance. In particular, it examines the influence of GD on the percentage of women hired by a company, female employee turnover, and recruitment of female managers. The study shows companies with high GD have a higher percentage of female employees and have greater female representation in managerial ranks. There was no support for higher GD and lower turnover among female employees.

\section{Introduction}

Research on the impact of gender-diverse boards of directors on corporate social responsibility (CSR) performance has yielded a rich stream of topics. Many studies support the assertion that gender diversity positively influences firms' CSR activities related to the environment (Stanwick and Stanwick 1998; Post et al, 2011; Rao et al, 2012; Harjoto et al, 2015), corporate sustainability (Chen and Van Staden, 2010; Galbreath, 2011; Htay, 2012; Cucari et al, 2017), philanthropy and giving (Kabongo et al, 2013), and occupational safety and health (Ruiz-Frutos et al, 2019). Recently, researchers found that greater gender diversity on management teams influences a company's choice of CSR initiatives (Cannella et al. 2008; Huang, 2013; Setó-Pamies, 2015; Rao and Tilt, 2020) because diverse boards bring a broader perspective to corporate decision making resulting in more encompassing solutions to problems (Erhardt, et al., 2003; Hussain, et al, 2018; Mahadeo, et al., 2012). In particular, female board members tend to place greater emphasis on actions supporting social wellbeing (Terjesen et al., 2009; Galbreath, 2011; Adams et al., 2015) and therefore lend a stronger focus to sustainability. This leads to better environmental outcomes (WEN and National Federation of Women's Institutes, 2007; Marshall, 2011; Orazalin and Baydauletov, 2020).

Contemporary research on gender and diversity converged to create a new area of inquiry within the purview of CSR research known as Gendered CSR (Grosser \& Moon https://ijbassnet.com/
2005; Pearson, 2007; Dovey, 2009; Thorpe-Jones et al. 2010; Kilgour 2013). This study contributes to the corpus of knowledge by employing Larrieta-Rubín de Celis, et al's definition of "the incorporation of gender equality objectives into all the different social responsibility initiatives implemented by an organization i.e. the guaranteeing by a company of equal opportunities for women and men through CSR practices and initiatives deployed both internally and externally" (Larrieta-Rubín de Celis, et al., 2015: 93). This paper advances the understanding of Gendered CSR (GCSR) by examining how the proportion of female board member's influences outcomes aimed at improving the status of women within organizations. In particular, we focus on human resource management outcomes intended to enhance recruitment, retention, and movement of women into managerial ranks. Toward this end, we explore the question "Do firms with a greater representation of women on boards result in higher Gendered CSR performance?" The study employs a sample of 458 firms reported in the 2018 Robeco Annual Corporate Sustainability Assessment.

This paper is organized as follows. Section 2 presents a review of the literature and hypothesis development. Section 3 details research methods and results. Section 4 discusses the limitations and future research directions.

\section{Literature Review and Hypotheses}

The growing representation of women at the highest levels of organizations has increased awareness of the unioue 


\section{(c) Center for Promoting Education and Research (CPER) USA}

www.cpernet.org

needs of women in the workplace and advanced the study of Gendered Corporate Social Responsibility (Karam and Jamali, 2013; Grosser and Moon, 2017). Companies with strong GCSR policies are likely to have a larger percentage of female employees, promote more women to the managerial ranks, and experience lower turnover among female employees.

A large female representation is likely to increase the board's awareness of women's issues (Bernardi and Threadgill., 2010; Jamali et al., 2007; Konrad et al., 2008) and therefore advance business practices amenable to women's needs. Similarly, female board members are more apt to propose initiatives that support and promote women in organizations (Nie et al., 2018). This may be explained by two theories. The first, Byrne's (1971) similarity-attraction paradigm posits individuals of the same gender are more likely to have life experiences in common and possess similar ways of looking at the world. Female board members are therefore likely to recognize gaps in organizational policies and practices and propose the corresponding action. The second, homosocial reproduction (Kanter, 1977; Elliott and Smith, 2004) asserts that people tend to hire others who are similar to themselves. This leads to the following hypothesis:

H1a: Firms with boards characterized by high gender diversity will have a higher percentage of female employees than firms with boards characterized by low gender diversity.

Studies of female turnover suggest that women leave organizations because of culture, policies, and practices (Griffeth et al., 2000; Hearn et al., 2015; Piszczek, 2020). Boards with a large representation of women show a greater awareness of women's issues (Bernardi and Threadgill, 2010; Brieger et al., 2019) and are more likely to propose and implement policies that favor the interests of women in the organization (Tsui, et al., 1992; Peccei \& Lee, 2005; Lewellyn \& Muller-Kahle, 2019). Such organizations are more likely to have human resource practices that support women's career goals while paying attention to issues such as family-work balance (Gilbert et al., 1999; Jamali et al., 2015) resulting in lower turnover (Nie et al., 2018). Organizations with a large representation of female managers tend to retain more women because they are perceived as less discriminatory in the eyes of female workers (Lucifora and Vigani, 2016). Similarly, women in upper management may serve as role models, advocate for, and mentor female coworkers thereby creating a more hospitable environment and reducing turnover (Athey et al., 2000; Koenig et al., 2011; Nasir et al., 2019).

This leads to the following hypothesis:

H1b: Firms with boards characterized by high gender diversity will have lower female employee turnover than firms with boards characterized by low gender diversity.
The presence of a large number of female managers establishes a virtuous circle which results in the hiring of more female managers (Hirsch, 2013; Hensvik, 2014; Bossler et al., 2020). This may be due to a demonstration effect in which women seeing other women at the managerial level no longer strongly associate leadership with masculinity (Koenig et al., 2011; Kunze and Miller, 2017; Bossler et al., 2020).

This leads to the following hypotheses:

H1c: Firms with boards characterized by high gender diversity will have a higher percentage of female managers than firms with boards characterized by low gender diversity.

\section{Research Methods and Results}

Data from the 2018 Robeco Corporate Sustainability Assessment (CSA) was used in this study. The CSA analyzes approximately 4,500 publicly listed companies to compile the Dow Jones Sustainability Indices (DJSI) and the S\&P ESG Factor Weighted Index. The CSA has been used in previous corporate social responsibility studies (Churet and Eccles, 2014; Eccles, 2015; Russell and Friend, 2018; Taylor, et al, 2018; Olkkonen and Quarshie, 2019; Campra et al., 2020).

\subsection{Dependent Variables}

The dependent variables used in this study are the number of female employees, the percentage of female managers, and female employee turnover as a percentage of total turnover. Using data from the Bloomberg financial database the number of female employees was extracted. The percentage of female managers was reported in the Robeco Corporate Sustainability Assessment. Female employee turnover was computed by dividing female employee attrition by total employee turnover from statistics reported in the Bloomberg financial database.

\subsection{Independent Variable}

The independent variable used in this study is board gender diversity which is calculated by dividing the number of women directors by the total number of directors. It follows previous studies by McWilliams and Siegel, (2001) and Khan et al., (2013). Sample firms were classified either as high gender diversity or low gender diversity using the methodology employed by Baker, et al (2020). Data on board membership about numbers and gender were collected from company annual reports and board of director composition appearing in the Bloomberg financial database.

\subsection{Results}

We employ the methodology used by Bhuiyan \& Nguyen (2019) to test the three hypotheses. Table 1 presents the mean, mean difference, t-ratios for sample companies categorized as either high or low on board gender diversity.

Hypothesis 1a: Firms with boards characterized by high gender diversity will have a higher percentage of female employees than firms with boards characterized by low gender diversity was supported. High gender diversity firms had an 
average of $43.79 \%$ women employees compared to $26.84 \%$ for low gender diversity companies $(\mathrm{t}=0.00)$.

Hypothesis 1b: Firms with boards characterized by high gender diversity will have lower female employee turnover than firms with boards characterized by low gender diversity was not supported. Companies with high gender diversity exhibited an average of $16.73 \%$ female turnover compared to $12.15 \%$ turnover for low gender diversity companies $(\mathrm{t}=$ 0.00). Groeneveld, (2011) suggests this counterintuitive finding may be due to the presence of a noticeable percentage of female employees from minority groups. The belief is there is a mismatch between human resource practices suitable for members of the dominant culture and the needs of minority employees. Alternatively, this may be due to the existence of diversity fault lines which "may split a group into subgroups based on one or more attributes and they provide an informal structure for intragroup conflict" (Lau \& Murnighan, 2005: 645).

Hypothesis 1c: Firms with boards characterized by high gender diversity will have a higher percentage of female managers than firms with boards characterized by low gender diversity was supported. High gender diversity companies reported a mean of $22.69 \%$ female managers in contrast with $15.28 \%$ for low gender diversity companies $(\mathrm{t}=0.00)$.

\section{Table 1. Difference Between Variable Mean Scores for Sample Firms n=458}

$\begin{array}{llllll}\text { Variable } & \begin{array}{l}\text { Gender } \\ \text { Diversity }\end{array} & \begin{array}{l}\text { Number } \\ \text { of Firms }\end{array} & \text { Mean } & \text { Mean Diff } & \text { t-ratio } \\ \text { \%Fem Managers } & \text { Low } & 245 & 15.28 & -7.41 & 0.00^{* *} \\ & \text { High } & 213 & 22.69 & & \\ \text { \%Fem Employees } & \text { Low } & 245 & 26.84 & -16.95 & 0.00^{* *} \\ & \text { High } & 213 & 43.79 & & \\ \text { \%Fem Directors } & \text { Low } & 245 & 19.78 & -11.75 & 0.00^{* *} \\ & \text { High } & 213 & 31.53 & & \\ \text { \%Female Turnover } & \text { Low } & & & & \\ & \text { High } & 245 & 12.15 & -4.58 & 0.00^{* *} \\ & & & & & \end{array}$

\section{Limitations and Future Research Directions}

This study suffers from three limitations. First, the companies appearing in the RobecoSam sustainability report are very large, publicly-traded entities primarily from North America, Europe, and the Asia/Pacific region. Consequently, the findings are not necessarily generalizable for companies in other regions and are likely not representative of practice among small and medium-sized enterprises. Second, all companies are either multinational or global in scope and are therefore likely to launch GCSR initiatives to emulate best practice instead of responding exclusively to home country legislation or societal change. Third, only a small number of companies from emerging markets particularly the Middle East and North Africa appeared in the survey. This limits our understanding of the evolution of GCSR in fast-growing, nonWestern countries.

There are three promising areas for future research. The first would entail comparing the relationship between board gender diversity and GCSR outcomes in publicly traded and privately held medium-size enterprises that originate in the same country or geographic region. Such a study would shed light on the factors driving GCSR initiatives- emulating a growing practice among companies that operate internationally or a response to legislative and social change. The second would focus on examining the board of director gender diversity and GCSR in companies based in emerging markets. 


\section{(C) Center for Promoting Education and Research (CPER) USA}

www.cpernet.org

The third area of research may examine how global companies and practices.

GCSR practices vary in response to host country legislation

\section{References}

Adams, R. B., de Haan, J., Terjesen, S., \& van Ees, H. (2015). Board diversity: Moving the field forward. Corporate Governance: An International Review, 23(2), 77-82.

Athey, Susan, Christopher Avery, and Peter Zemsky, “Mentoring and Diversity," American Economic Review 90 (2000), 765-786.

Baker, H.K., Pandey, N., Kumar, S., and Haldar, A. (2020). A bibliometric analysis of board diversity: Current status, development, and future research directions. Journal of Business Research, 108, pp.232-246.

Bernardi, R.A. and Threadgill, V.H. (2010). 'Women directors and corporate social responsibility'. Electronic Journal of Business Ethics and Organization Studies, 15:2, 15-21.

Bhuiyan, M. B. U., \& Nguyen, T. H. N. (2019). Impact of CSR on cost of debt and cost of capital: Australian evidence. Social Responsibility Journal.

Bossler, M., Mosthaf, A., \& Schank, T. (2020). Are female managers more likely to hire more female managers? Evidence from Germany. ILR Review, 73(3), 676-704.

Brieger, S. A., Francoeur, C., Welzel, C., \& Ben-Amar, W. (2019). Empowering women: The role of emancipative forces in board gender diversity. Journal of Business Ethics, 155(2), 495-511.

Byrne, D. E. (1971). The attraction paradigm (Vol. 462). Academic Press.

Campra, M., Sabrina, P. and Brescia, V., 2020. Can the Dow Jones Sustainable Index be Useful for Evaluating Dow Jones Islamic Market Companies?.

Cannella Jr, A. A., Park, J. H., \& Lee, H. U. (2008). Top management team functional background diversity and firm performance: Examining the roles of team member colocation and environmental uncertainty. Academy of management Journal, 51(4), 768-784.

Chen, X. and Van Staden, C. (2010). Stakeholder pressure, social trust, governance and the disclosure quality of environmental information. APIRA, Sydney.

Churet, C., \& Eccles, R. G. (2014). Integrated reporting, quality of management, and financial performance. Journal of Applied Corporate Finance, 26(1), 56-64.

Cucari, N., Esposito De Falco, S., and Orlando, B. (2017). Diversity of Board of Directors and Environmental Social Governance: Evidence from Italian Listed Companies, Corporate Social Responsibility and Environmental Management, 25 (3) 250-266.

Dovey, K. (2009). Putting Gender on the Business and Human Rights Agenda Scoping Paper. Realizing Rights-The Ethical Globalization Initiative, available at:

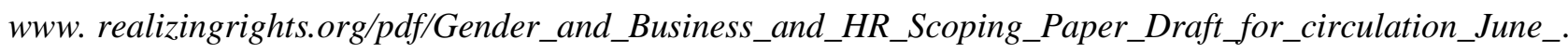

Eccles, R. G., Krzus, M. P., \& Ribot, S. (2015). Meaning and momentum in the integrated reporting movement. Journal of Applied Corporate Finance, 27(2), 8-17.

Elliott, J., and R. Smith. 2004. Race, gender, and workplace power. American Sociological Review 69:365-86.

Erhardt, N. L., Werbel, J. D., \& Shrader, C. B. (2003). Board of director diversity and firm financial performance. Corporate governance: An international review, 11(2), 102-111.

Galbreath, J. (2011). Are there gender-related influences on corporate sustainability? A study of women on boards of directors. Journal of Management \& Organization, 17, 17-38.

Gilbert, J. A., Stead, B. A., and Ivancevich, J. M. 1999. 'Diversity management: a new organizational paradigm.' Journal of Business Ethics, 21:1, 61-76.

Griffeth, R. W., Hom, P. W. and Gaertner, S. 2000. 'A meta-analysis of antecedents and correlates of employee turnover: Update, moderator tests, and research implications for the next millennium.' Journal of Management, 26, 463-488.

Groeneveld, S. (2011). Diversity and employee turnover in the Dutch public sector. International Journal of Public Sector Management. 
Grosser, K., \& Moon, J. (2005). Gender mainstreaming and corporate social responsibility: Reporting workplace issues. Journal of business ethics, 62(4), 327-340.

Grosser, K., \& Moon, J. (2017). CSR and feminist organization studies: Towards an integrated theorization for the analysis of gender issues. Journal of Business Ethics, 1-22.

Harjoto, M., Laksmana, I., \& Lee, R. (2015). Board diversity and corporate social responsibility. Journal of Business Ethics, 132(4), 641-660.

Hearn, J., Lämsä, A., Biese, I., Heikkinen, S., Louvrier, J., Niemistö, C., Kangas, E., and Koskinen, P. (2015). 'Opening Up New Opportunities for Gender Equality Work.' Helsinki: Edita Publishing (Hanken School of Economics Research Reports 76).

Hensvik, L. (2014). “Manager impartiality: Worker-firm matching and the gender wage Gap”, Industrial and Labor Relations Review 67, 395-421.

Hirsch, B. (2013). "The impact of female managers on the gender pay gap: Evidence from linked employer-employee data for Germany", Economics Letters119(3), 348-350.

Huang, S. K. (2013). The impact of CEO characteristics on corporate sustainable development. Corporate Social Responsibility and Environmental Management, 20(4), 234-244.

Hussain, N., Rigoni, U., \& Orij, R. P. (2018). Corporate governance and sustainability performance: Analysis of triple bottom line performance. Journal of Business Ethics, 149(2), 411-432.

Htay, S. N. N., Rashid, H. M. A., Adnan, M. A. and Meera, A. K. M. (2012). Impact of Corporate Governance on Social and Environmental Information Disclosure of Malaysian Listed Banks: Panel Data Analysis. Asian Journal of Finance \& Accounting, 4, 1-24.

Jamali, D., Safieddine, A. and Daouk, M. 2007. 'Corporate governance and women: an empirical study of top and middle women managers in the Lebanese banking sector'. Corporate Governance , 7:5, 574-585.

Jamali, D. R., El Dirani, A. M. and Harwood, I. A. (2015). 'Exploring human resource management roles in corporate social responsibility: the CSR-HRM co-creation model.' Business Ethics: A European Review, 24:2, 125-143.

Kabongo, J. D., Chang, K. and Li, Y. (2013). The impact of operational diversity on corporate philanthropy: An empirical study of US companies. Journal of Business Ethics, 116, 49-65.

Kanter, Rosabeth Moss. (1977). Men and women of the corporation. New York: Basic Books.

Karam, C. M., \& Jamali, D. (2013). Gendering CSR in the Arab Middle East: An institutional perspective. Business Ethics Quarterly, 23(1), 31-68.

Khan A, Muttakin MB, Siddiqui J. 2013. Corporate governance and corporate social responsibility disclosures: Evidence from an emerging economy. Journal of Business Ethics 114(2): 207-223.

Kilgour, M. A. (2013). The global compact and gender inequality: a work in progress. Business \& Society, 52(1), 105-134.

Konrad, A. M., Kramer, V., \& Erkut, S. (2008). Critical Mass: The Impact of Three or More Women on Corporate Boards. Organizational dynamics, 37(2), 145-164.

Koenig, Anne M., Eagly, A.H., Mitchell, A., and Ristikari. T. (2011) “AAre Leader Stereotypes Masculine? A Meta-Analysis of Three Research Paradigms," Psychological Bulletin 137, 616-642.

Kunze, A and Miller, A. (2017). "Women Helping Women? Evidence from Private Sector Data on Workplace Hierarchies." Review of Economics and Statistics, Vol 99 (5) p.p. 769-775

Larrieta-Rubín de Celis, I., Velasco-Balmaseda, E., Fernández de Bobadilla, S., del Mar Alonso-Almeida, M., and IntxaurburuClemente, G. 2015. 'Does having women managers lead to increased gender equality practices in corporate social responsibility?' Business Ethics: A European Review, 24: 1, 91-110.

Lau, D. C., \& Murnighan, J. K. (2005). Interactions within groups and subgroups: The effects of demographic faultlines. Academy of Management Journal, 48(4), 645-659.

Lewellyn, K. B., \& Muller-Kahle, M. I. (2019). The corporate board glass ceiling: The role of empowerment and culture in shaping board gender diversity. Journal of Business Ethics, 1-18.

Lucifora, C. and Vigani, D. (2016), What if your boss is a woman? Work organization, work-life balance and gender discrimination at the workplace, IZA Discussion Paper No. 9737, Institute for the Study of Labor, Bonn. 
Mahadeo, J. D., Soobaroyen, T., \& Hanuman, V. O. (2012). Board composition and financial performance: Uncovering the effects of diversity in an emerging economy. Journal of Business Ethics, 105(3), 375-388.

Marshall, J. 2011. En-gendering notions of leadership for sustainability. Gender, Work \& Organization, 18(3): $263-281$.

McWilliams A, Siegel D. 2001. Corporate social responsibility: A theory of the firm perspective. Academy of Management Review 26(1): 117-127.

Nasir, F., Ashraf, M., \& Riaz, M. (2019). The Role of Gender in Employee Retention: A Study of Private Hospitals in Karachi. International Journal of Experiential Learning \& Case Studies, 4(1), 157-171.

Nie, Dan-Lämsä, Anna-Maija Pucetaite, Raminta. (2018). Effects of Responsible Human Resource Management Practices on Female Employees' Turnover Intentions. Business Ethics: A European Review 27 (1), 29-41.

Olkkonen, L. and Quarshie, A., 2019. Positioning the CSR Performance of Finnish Companies. In Corporate Social Responsibility in Finland (pp. 77-84). Palgrave Pivot, Cham.

Orazalin, N., \& Baydauletov, M. (2020). Corporate social responsibility strategy and corporate environmental and social performance: The moderating role of board gender diversity. Corporate Social Responsibility and Environmental Management.

Pearson, R. (2007). Beyond women workers: Gendering CSR. Third World Quarterly, 28(4), 731-749.

Peccei, R. and Lee, H. J. 2005. 'The impact of gender similarity on employee satisfaction at work: a review and re-evaluation.' Journal of Management Studies, 42:8, 1571-1584.

Piszczek, M. M. (2020). Reciprocal relationships between workplace childcare initiatives and collective turnover rates of men and women. Journal of Management, 46(3), 470-494.

Post, C., Rahman, N. and Rubow, E. (2011). Green Governance: Boards of Directors' Composition and Environmental Corporate Social Responsibility. Business \& Society, 50, 189-223.

Rao, K. K., Tilt, C. A. and Lester, L. H. (2012). Corporate governance and environmental reporting: an Australian study. Corporate Governance, 12, 143-163.

Rao, K. K., \& Tilt, C. (2020). Gender and CSR decisions: perspectives from Australian boards. Meditari Accountancy Research.

Robeco: 2018 Annual Corporate Sustainability Assessment. Accessed July 8, 2020. https://www.spglobal.com/esg/csa/indices/

Ruiz-Frutos, C., Pinos-Mora, P., Ortega-Moreno, M. and Gómez-Salgado, J., (2019). Do companies that claim to be socially responsible adequately manage occupational safety and health?. Safety Science, 114, pp.114-121.

Russell, W. G., \& Friend, G. (2018). Enterprise sustainability metrics and reporting: Performance measurements for resilient strategic progress. In The Sustainable Enterprise Fieldbook (pp. 287-354). Routledge.

Setó-Pamies, D. (2015). The relationship between women directors and corporate social responsibility. Corporate Social Responsibility and Environmental Management, 22(6), 334-345.

Stanwick, P. A. and Stanwick, S. D. (1998). The relationship between corporate social performance and organizational size, financial performance, and environmental performance: An empirical examination. Journal of Business Ethics, 17, 195-204.

Taylor, J., Vithayathil, J., \& Yim, D. (2018). Are corporate social responsibility (CSR) initiatives such as sustainable development and environmental policies value enhancing or window dressing?. Corporate Social Responsibility and Environmental Management.

Terjesen, S., Sealy, R., \& Singh, V. (2009). Women directors on corporate boards: A review and research agenda. Corporate governance: an international review, 17(3), 320-337.

Thorpe-Jones, E., Dainty, A., \& Fellows, R. (2010, September). Enacting diversity and equality as part of CSR policy: an agenda for change. In Procs 26th Annual ARCOM Conference (pp. 6-8).

Tsui, A. S., Egan, T. D. and O'Reilly, C. A. 1992. 'Being different: Relational demography and organizational attachment.' Administrative Science Quarterly, 37, 547-579.

WEN and National Federation of Women's Institutes (2007) Women's Manifesto on Climate Change. Available at: http://www.wunrn.com/news/2007/09_07/09_10_07/091607_womens_files/091607_womens.pdf 